\title{
Empirical Models of Potassium Uptake by Dieffenbachia amoena 'Tropic Snow' Under Different Nitrogen Sources
}

\section{Silvia Jiménez Becker1, Blanca María Plaza, and María Teresa Lao Departament de Producción Vegetal, Escuela Politécnica Superior, Universidad de Almería, Almería 04120, Spain}

Additional index words. potassium and water uptake ratio, leaf area index, vapor deficit pressure, global radiation, temperature, water uptake

\begin{abstract}
Nutritional solution composition in fertigation must be designed according to crop needs. These needs are variable and depend on factors like plant growth rate, environmental conditions, and water uptake. The objective of this work is to study the influence of the $\mathrm{N}$-form supply $\left(\mathrm{N}-\mathrm{NO}_{3}{ }^{-}\right.$or $\left.\mathrm{N}_{-} \mathrm{NH}_{4}{ }^{+}\right)$on the potassium uptake and potassium concentration changes on the recycled solution and the development of empirical models that permit the prediction of the potassium nutritional needs of Dieffenbachia amoena, 'Tropic Snow'. To achieve this, potassium uptake has been correlated to temperature, vapor pressure deficit, global radiation, and leaf area index. The plants were placed in a Buried Solar Greenhouse, the plants being supplied with equal amounts of nitrogen, differing in the percentage of the N-form applied $\left(\mathrm{NO}_{3}{ }^{-}: \mathrm{NH}_{4}{ }^{+}\right)$: Ta (100:0), Tb (50:50), and Tc (0:100). Seasons (winter and summer) generate important differences in the potassium concentration changes in the recycled solution but are not influenced by the nitrogen form. In winter, the potassium concentration remains constant, whereas in summer conditions, there is a higher decrease. This difference in behavior should be considered in the nutritive solution formulation. The nitrogen form applied does not affect potassium uptake. The study also indicates the possibility of predicting the potassium (K) uptake using the proposed models. $K$ uptake can be estimated with a model dependent on the leaf area index, and potassium uptake concentration can be estimated with $\mathrm{K}$ uptake through the model and the experimental water uptake.
\end{abstract}

Potassium $(\mathrm{K})$ is an essential element for all living organisms. In plant physiology, it is the most important cation not only in regard to its content in plant tissues, because it is the most abundant cation in plant tissues (Triboulot et al., 1997), but also with respect to its physiological and biochemical functions. Potassium is a mobile carrier of positive charges, a cofactor of enzymes, e.g., in protein synthesis and glycolysis, and an osmoticum for turgor movements (Mohr and Schopfer, 1995). Plants have multiple mechanisms for $\mathrm{K}^{+}$uptake from soil and translocation to various plant tissues to help them respond to changing environmental conditions and the varying $\mathrm{K}^{+}$requirements in different tissues (Ju et al., 2004). One main feature of $\mathrm{K}^{+}$is the high rate at which it is taken up by plant tissues. This high uptake rate depends on an active uptake mechanism, and there is evidence that of all the essential mineral cation classes, $\mathrm{K}^{+}$is the only one that can be transported against an electrochemical gradient into plant cells (Mengel and Kirkby, 2001). $\mathrm{K}^{+}$uptake can be affected by nitrogen

Received for publication 18 Sept. 2008. Accepted for publication 10 Dec. 2008.

${ }^{1}$ To whom reprint requests should be addressed; e-mail sbecker@ual.es.
(N) source. The interactions of $\mathrm{N}$ source depend on different factors such as initial potassium concentration in the nutrient solution and $\mathrm{N}-\mathrm{NO}_{3}{ }^{-}: \mathrm{NH}_{4}{ }^{+}$relation $(\mathrm{Lu}$ et al., 2005). So depending on the species, the presence of $\mathrm{N}-\mathrm{NH}_{4}{ }^{+}$in the nutrition solution may inhibit the $\mathrm{K}$ uptake (Bar-Tal et al., 2001; Guo et al., 2002), which suggests $\mathrm{NH}_{4}{ }^{+}-\mathrm{N}$ is competing with these cations for uptake (Chance et al., 1999) or may have little effect (Bloom and Finazzo, 1986)

Increased fertilizer demand resulting from the growth in global population and the expansion of agriculture into less productive areas has increased the cost of fertilizers and decreased fertilizer use efficiency (Rengel and Damon, 2008). Intensive crop production typically involves the application of an excessive amount of many nutrients as a precaution. Thus, although the application of excessive amounts of fertilizers has been commonplace in many horticultural systems, methods must be found to reduce this excess to protect the environment and human health (Silberbush and Lieth, 2004). To obtain high yields and good quality in commercial crops grown hydroponically, the nutrient solution supplied to the plants must be specific for the particular crop, the growth stage, the climatic conditions, the substrate, or the hydroponic system used (Savvas et al., 2003). Models that permit the estimation of the nutrient uptake can be useful tools for integrated fertigation management, permitting a more rational use of the nutrients and a higher water and fertilizer use efficiency (Jiménez et al., 2007, 2008). There are not many empirical models that describe $\mathrm{K}$ uptake. In some examples, Pardossi et al. (2004) used as independent variables global radiation and air temperature in the greenhouse, crop age, and the uptake of water. Silberbush and BenAsher (2001) evaluated the $\mathrm{K}$ uptake in function of cumulative transpiration and $\mathrm{NaCl}$ level.

The aims of this work are: 1) the study of potassium concentration change in recycled solution with different $\mathrm{N}-\mathrm{NO}_{3}{ }^{-} / \mathrm{N}-\mathrm{NH}_{4}{ }^{+}$ ratios; 2) the influence of the $\mathrm{N}$-form supply $\left(\mathrm{N}_{-} \mathrm{NO}_{3}{ }^{-}\right.$or $\left.\mathrm{N}-\mathrm{NH}_{4}{ }^{+}\right)$on potassium uptake; and 3 ) the development of empirical models that permit the prediction of the K nutritional needs of Dieffenbachia amoena. To achieve this, $\mathrm{K}$ uptake has been correlated to temperature (T), vapor pressure deficit (VPD), global radiation $(\mathrm{Rg})$, and leaf area index (LAI).

\section{Materials and Methods}

Plant growth environment and irrigation systems. The trial was carried out in a $150-\mathrm{m}^{2}$ Buried Solar Greenhouse with zenithal ventilation and relative humidity and temperature control equipment.

The variety studied was Dieffenbachia amoena 'Tropic Snow'. The plant density was 3.2 plants $/ \mathrm{m}^{2}$. Single plants were grown in a $17-\mathrm{cm}$ diameter pot and the substrate used was expanded clay ( 3 to $8 \mathrm{~mm}$ ). Two trials were conducted. The first trial was conducted from 10 Nov. to 9 June, $200 \mathrm{~d}$ after transplanting (DAT), and the second trial was carried out from 19 Dec. to 13 Aug., 240 DAT. During both trials, the crops were in a vegetative phenological state.

A recycled fertigation system was used. The fertilizer was applied through drip irrigation, with one emitter per plant, having a flow rate of $2 \mathrm{~L} / \mathrm{h} / \mathrm{emitter}$. During the experiment, each irrigation lasted $1 \mathrm{~min} 15 \mathrm{~s}$ and the timing was one irrigation every $10 \mathrm{~min}$.

Nutritional treatments. There were three tested treatments, differing in the percentage of the $\mathrm{N}$ form applied $\left(\mathrm{NO}_{3}{ }^{-}: \mathrm{NH}_{4}{ }^{+}\right)$: Ta (100:0), Tb (50:50), and Tc (0:100). Irrigation water and $\mathrm{KNO}_{3}, \mathrm{NH}_{4} \mathrm{NO}_{3}, \mathrm{Mg}\left(\mathrm{NO}_{3}\right)_{2}$, $\mathrm{K}_{2} \mathrm{SO}_{4}, \mathrm{SO}_{4}\left(\mathrm{NH}_{4}\right)_{2}, \mathrm{Mg} \mathrm{SO}_{4}, \mathrm{H}_{3} \mathrm{PO}_{4}$, and Nutrel $\mathrm{C}$ as mineral fertilizers were used to prepare the nutrient solutions. Nutrel $\mathrm{C}$ is a combination of micronutrients with the following composition: boron $0.7 \%$, copper $0.3 \%$, iron $7.5 \%$, manganese $3.3 \%$, molybdenum $0.2 \%$, and zinc $0.6 \%$. The nutrient solutions used are listed in Table 1. The fertigation system was equipped with a 500 $\mathrm{L}$ tank with the final nutrient solution needed for each treatment. During the experiment, the leaching of each pot was collected through a drain pipe placed below each pot and it was redirected toward the mother tank. The recycled solution was renewed every $20 \mathrm{~d}$ to adjust the nutrient concentration to 
Table 1. Concentrations ions $\left(\mathrm{mmol} \cdot \mathrm{L}^{-1}\right), \mathrm{pH}$, and electrical conductivity $\left(\mathrm{EC} ; \mathrm{dS} \cdot \mathrm{m}^{-1}\right)$ of the used nutrient solution.

\begin{tabular}{lccccccccc}
\hline Treatments $\left(\mathrm{NO}_{3}^{-}: \mathrm{NH}_{4}^{+}\right)$ & $\mathrm{pH}$ & $\mathrm{EC}$ & $\mathrm{NO}_{3}^{-}$ & $\mathrm{NH}_{4}^{+}$ & $\mathrm{H}_{2} \mathrm{PO}_{4}^{-}$ & $\mathrm{SO}_{4}{ }^{2-}$ & $\mathrm{K}^{+}$ & $\mathrm{Ca}^{2+}$ & $\mathrm{Mg}^{2+}$ \\
\hline $\mathrm{Ta}(100: 0)$ & 6.5 & 1.0 & 6.0 & 0.0 & 1.2 & 1.0 & 4.0 & 0.9 & 2.4 \\
$\mathrm{~Tb}(50: 50)$ & 6.5 & 1.4 & 3.0 & 3.0 & 1.2 & 4.0 & 4.0 & 0.9 & 2.4 \\
$\mathrm{Tc}(0: 100)$ & 6.5 & 1.8 & 0.0 & 6.0 & 1.2 & 7.5 & 4.0 & 0.9 & 2.4 \\
\hline
\end{tabular}

the initial values; no change in nutrient solutions was done during these days. The concentration of $\mathrm{K}$ was analyzed using photometry (Spanish Ministry of Agriculture and Fishing, 1994).

Sampling. Climatic parameters were monitored by means of an LCC 900 VOLMATIC (DGT-Volmatic, Barcelona, Spain) climate computer. External radiation was measured every 15 min with a sensor Q20-B (DGT-Volmatic), whereas temperature and humidity were recorded with a sensor RTV-5B (DGT-Volmatic). To estimate the internal radiation, the cover transmission coefficient was estimated every 2 weeks as a ratio between internal and external radiation being measured with manual equipment A quantum-photoradiometer, Delta OHM, model RAD/PAR (Dicsa, Almería, Spain). A shade screen was used during the summer season to avoid excessive radiation and reduce temperature in the greenhouse.

VPD was estimated in accordance with Jiménez et al. (2007).

Leaf area was estimated by a nondestructive method in accordance with Jiménez et al. (2007).

Water uptake. The water uptake was estimated as the difference between the initial and the final volume in a transparent tube previously calibrated and fixed to the nutritive solution tank. The precision of the reading is $1 \mathrm{~mL}$. The measurements correspond to an interval of $20 \mathrm{~d}$.

Estimation of potassium uptake and potassium uptake concentration. Net uptake was measured every $20 \mathrm{~d}$ and estimated in accordance with Jiménez et al. (2007). The potassium uptake concentration $\left(\mathrm{mmol} \cdot \mathrm{L}^{-1}\right)$ can be defined as potassium uptake ( $\mathrm{mmol} / \mathrm{d} / \mathrm{plant})$ per unit of water uptake (L/d/plant). The nutrient solution was collected daily during $20 \mathrm{~d}$ in winter (120 DAT) and summer seasons (200 DAT) to study the $\mathrm{K}$ concentration changes of recycled solution.

Percentage of leaf potassium. At the end of the experiment, one uppermost mature leaf for each replication, treatment, and plant was collected. The percentage of $\mathrm{K}$ leaf was determined by photometry (Spanish Ministry of Agriculture and Fishing, 1994).

Experimental design and statistical anal$y$ sis. The experimental design was unifactorial ( $\mathrm{N}$ form) with three treatments, three replications per treatment, and 20 plants per replication during the two crop cycles. Analysis of data were made using the software packages Excel 7.0 and Statgraphics (Stat Point, Hemdon, VA) plus 4.0. Analysis of variance and least significant difference $(P<$ 0.05 ) were made to compare $\mathrm{K}$ uptake and shoot $\mathrm{K}$ concentration between treatments. Simple regressions between K uptake related to climatic and growth parameters were made to generate models. The number of observations was 162 and coefficients are significant at the $0.5 \%$ level. From all of the parameters considered, the one with a higher determination coefficient $\left(R^{2}\right)$ was selected as the principal parameter. Subsequently, multiple regression, including considering all the variables one by one, was made. The criterion for accepting a new variable in the model was the increase of $R^{2}$ and the lowest correlation coefficient between variables (Canavos, 1988).

A simple regression model between LAI related to DAT of 75 data set derived from the first year experiment was performed. Independent data sets from the second year of experiments were used for model validation. The validation consisted of the comparison line regression between experimental observations and values predicted by the model. Before the model validation was performed and as a result of the data showing an exponential tendency, log transformations were used to linearize them.

\section{Results and Discussion}

Climatic and growth parameters during the crop. Average values of T, Rg, and VDP for both years are shown in Table 2. The climatic parameter ranges are very narrow and at the optimal setting for these species.

Potassium concentration changes during crop. Figure 1 shows changes of $\mathrm{K}$ concentration in the recycling solution under winter and summer conditions over $20 \mathrm{~d}$. The $\mathrm{N}$ form does not generate modifications in concentration $\mathrm{K}$ change in the recirculating solution. There are no statistical differences $(P<0.05)$ among $\mathrm{Ta}, \mathrm{Tb}$, and $\mathrm{Tc}$. However, growth stage causes a difference in the evolution of the recycled solution. In winter, when the temperature was low and the plant was small, $\mathrm{K}$ concentration was practically constant. However, in summer, all the treatments have an

Table 2. Average temperature $\left(\mathrm{T} ;{ }^{\circ} \mathrm{C}\right)$, global radiation $\left(\mathrm{Rg} ; \mathrm{MJ} \cdot \mathrm{m}^{-2} \cdot \mathrm{d}^{-1}\right)$, and vapor pressure deficit $(\mathrm{VPD}$; $\mathrm{kPa})$ in the greenhouse during the growth period for both years.

\begin{tabular}{|c|c|c|c|c|c|c|}
\hline \multirow[b]{2}{*}{ DAT } & $\mathrm{Rg}$ & VPD & \multirow[t]{2}{*}{$\mathrm{T}$} & $\mathrm{Rg}$ & VPD & $\mathrm{T}$ \\
\hline & & First tria & & \multicolumn{3}{|c|}{ Second trial } \\
\hline 40 & & & & 2.57 & -0.25 & 20. \\
\hline 60 & & & & 2.49 & -0.30 & 18.3 \\
\hline 80 & 2.21 & -0.74 & 22.6 & 2.41 & -0.30 & 18.5 \\
\hline 100 & 6.22 & -1.01 & 26.6 & 3.07 & -0.44 & 18.7 \\
\hline 120 & 5.96 & -0.88 & 26.1 & 3.78 & -0.55 & 20.8 \\
\hline 140 & 2.94 & -0.93 & 27.2 & 4.13 & -0.29 & 22.6 \\
\hline 160 & 3.73 & -0.35 & 31.2 & 5.52 & -0.51 & 24.9 \\
\hline 180 & 3.46 & -0.07 & 29.1 & 6.30 & -0.27 & 24.4 \\
\hline 200 & 3.36 & -0.13 & 30.3 & 1.92 & -0.30 & 24.1 \\
\hline 220 & & & & 2.24 & -0.57 & 25.1 \\
\hline 240 & & & & 2.49 & -0.54 & 27.2 \\
\hline
\end{tabular}

$\mathrm{DAT}=$ days after transplanting. abrupt drop of 2 to $3 \mathrm{mmol} \cdot \mathrm{L}^{-1}$ in the recycled solution as a result of the difference in water and K uptake (Jiménez et al., 2008). Different authors have studied the evolution of the recycled solution and have obtained different results in function of the initial concentration of the recycled solution and studied species. Gislerod and Selmer-Olsen (1980) who worked with Chrysanthemum consider that with an initial concentration of the nutritive solution of 2.4 and $4.8 \mathrm{mmol} \cdot \mathrm{L}^{-1}$ of $\mathrm{K}$, there is a decrease in this cation; however, with a concentration of $9.6 \mathrm{mmol} \cdot \mathrm{L}^{-1}$, the tendency is to increase. Alt (1980) also carried out an experiment with different initial $\mathrm{K}$ concentrations in nutrient solution. With the first concentration $\left(12.8 \mathrm{mmol} \cdot \mathrm{L}^{-1}\right)$, he found a high increase, with the second $\left(6.0 \mathrm{mmol} \cdot \mathrm{L}^{-1}\right)$ the concentration was constant at the beginning and end of the crop, and the third (2.5 $\mathrm{mmol} \cdot \mathrm{L}^{-1}$ ) was always constant. However, D'Agliano et al. (1994) observed important fluctuations of this cation in the recycled solution and did not find a clear tendency in the Gerbera crop. This difference in behavior should be considered in the nutritive solution formulation. To maintain the recycled solution as much as possible, a concentration of potassium of $4 \mathrm{mmol} \cdot \mathrm{L}^{-1}$ in winter is adequate for Dieffenbachia amoena, but in summer, this concentration must be higher.

Effect of nitrogen source on potassium uptake. Figure 2 shows $\mathrm{K}$ uptake for all the treatments during the growth stage. Potassium uptake increased with time. However, Gent (2008) shows K uptake decreased later in the season in both years in tomato crop. The daily average net $\mathrm{K}$ uptake was $0.55,0.71$ and 0.51 $\mathrm{mmol} / \mathrm{d} / \mathrm{plant}$ for $\mathrm{Ta}, \mathrm{Tb}$, and $\mathrm{Tc}$ treatments, respectively (Table 3 ). These values are low in comparison with the ones obtained by another author in horticultural crops (Adams, 2004), but are in the same range as the ones obtained by Van Goor et al. (1988) in lettuce crop, maybe because both crops were in the vegetative phenological stage with low $\mathrm{K}$ requirements because $\mathrm{K}$ belongs to the group of elements with maximum extraction from fruit set to harvest. On the other hand, the $\mathrm{N}$ form applied does not affect $\mathrm{K}$ uptake. Also, K shoot concentration does not show any influence resulting from the $\mathrm{N}$ source (Table 3 ). Mengel and Kirkby (2001) observed that the plants fed with the $\mathrm{N}^{-\mathrm{NH}_{4}}{ }^{+}$source contained 


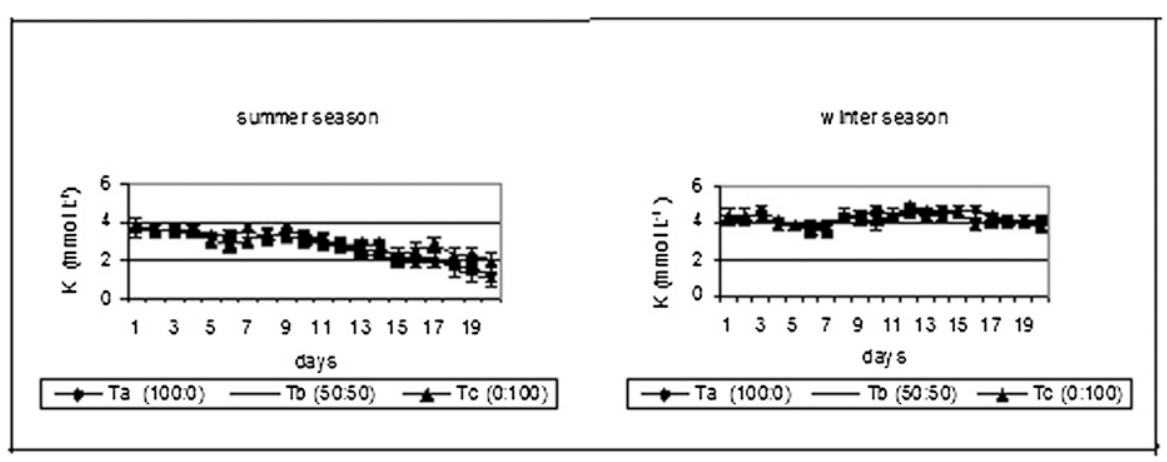

Fig. 1. Changes in potassium concentration in recycling solution under winter $[120 \mathrm{~d}$ after transplanting (DAT)] and summer conditions (200 DAT) during $20 \mathrm{~d}$.

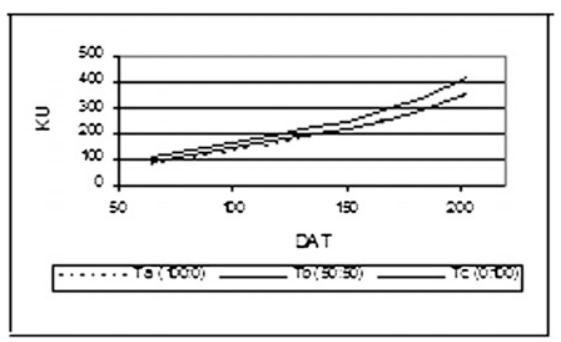

Fig. 2. Total potassium uptake $\left(\mathrm{KU} ; \mathrm{mmol} \cdot \mathrm{m}^{-2}\right)$ during the growth period. DAT $=$ days after transplanting.

higher concentrations of inorganic anions $\left(\mathrm{SO}_{4}{ }^{2-}, \mathrm{H}_{2} \mathrm{PO}_{4}^{-}, \mathrm{Cl}^{-}\right)$, whereas cations $\left(\mathrm{Ca}^{2+}\right.$, $\mathrm{Mg}^{2+}, \mathrm{K}^{+}$) were present in lower concentrations. In contrast, the plants supplied with the $\mathrm{N}^{-\mathrm{NO}_{3}}{ }^{-}$form contained higher cation content (Bar-Tal et al., 2001; Guo et al., 2002). The same result was obtained by Savvas et al. (2006) in lettuce crops and Savvas et al. (2003) in Gerbera 'Pink Elegance', but the higher $\mathrm{pH}$ level enhanced synergistically with the low $\mathrm{NH}_{4}{ }^{+}-\mathrm{N} /$ total $\mathrm{N}$ the leaf $\mathrm{K}$ concentrations in 'Eclipse'. Also, Lu et al. (2005) found that there was not difference in the amount of $\mathrm{K}^{+}$uptake by $\mathrm{N}-\mathrm{NO}_{3}{ }^{-}$and $\mathrm{N}-\mathrm{NO}_{3}{ }^{-}$$\mathrm{NH}_{4}{ }^{+}$-fed plants at the low nutrient level $(2.5$ mmol K), but by increasing the nutrient concentration $(6 \mathrm{mmol} \mathrm{K}), \mathrm{K}$ uptake increased

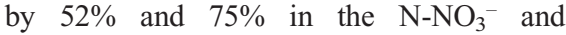
$\mathrm{NO}_{3}{ }^{-}: \mathrm{NH}_{4}{ }^{+}$-fed plants, respectively. This agrees with the proposed theory that cycling of $\mathrm{K}$ in plants can act as an important signal for feedback control of nutrient uptake (Lu et al., 2005). On the other hand, Wang et al. (2003) suggest that when total $\mathrm{NO}_{3}{ }^{-}-\mathrm{N}$ is replaced by $\mathrm{NH}_{4}^{+}-\mathrm{N}, \mathrm{K}$ uptake is substantially reduced. Also, in this case, the effect of ammonium was not observed in $\mathrm{Tc}$ when total $\mathrm{NO}_{3}{ }^{-} \mathrm{N}$ is replaced by $\mathrm{NH}_{4}^{+}-\mathrm{N}$, probably because in this treatment, part of the ammonium was con-

Table 3. Average of the potassium uptake $(\mathrm{mmol} / \mathrm{d} / \mathrm{plant}$ ), shoot potassium concentration (percent dry weight) and potassium (K) concentration in nutritive solution $\left(\mathrm{mmol} \cdot \mathrm{L}^{-1}\right)$ for $\mathrm{Ta}, \mathrm{Tb}$, and $\mathrm{Tc}$ treatments.

\begin{tabular}{lccc}
\hline Treatments $\left(\mathrm{NO}_{3}{ }^{-}: \mathrm{NH}_{4}{ }^{+}\right)$ & $\mathrm{K}$ uptake & Shoot $\mathrm{K}$ concn & K concn in nutritive solution \\
\hline $\mathrm{Ta}(100: 0)$ & $0.55 \pm 0.20 \mathrm{a}^{\mathrm{z}}$ & $3.63 \pm 0.12 \mathrm{a}$ & 4.00 \\
$\mathrm{~Tb}(50: 50)$ & $0.71 \pm 0.20 \mathrm{a}$ & $3.48 \pm 0.15 \mathrm{a}$ & 4.00 \\
$\mathrm{Tc}(0: 100)$ & $0.51 \pm 0.19 \mathrm{a}$ & $3.33 \pm 0.21 \mathrm{a}$ & 4.00 \\
\hline
\end{tabular}

${ }^{\mathrm{z}}$ Different letters indicate statistically significant differences at $P<0.05$. by the model. The model explains $98.51 \%$ of the experimental data measured in the second year. For this reason, the model can be considered validated.

Temperature and $\mathrm{K}$ uptake correlate well. Potassium uptake was highest when the air temperature was highest. Temperature is one of the major factors that affect plant growth and consequently nutrient demand and nutrient uptake. Potassium uptake also correlated with water uptake. From the slope of the line, the $\mathrm{K}$ uptake concentration can be obtained, its value being $6.47 \mathrm{mmol} \cdot \mathrm{L}^{-1}\left(R^{2}=0.60\right)$. Similar values were obtained by Sonneveld (2004) in Gerbera, cucumber, and tomato crop and Sheen and Hsu (1996) in melon crop. This parameter can be a useful tool for estimating nutrient concentrations in nutrient solution although some authors consider that nutrient uptake concentration varies between days depending on environmental conditions. In this case, there was not a good correlation between $\mathrm{K}$ uptake concentration and environmental condition (data not present).

Global radiation and VPD and nutrient uptake did not show a good correlation $\left(R^{2}=\right.$ 0.21 and 0.03 ). This may be because the interval of these two parameters (Table 2) during the growth period was very narrow. This result is in accordance with Silberbush and Lieth (2004); these authors observed that when a perennial plant like rose is grown under controlled conditions, as allowed by modern greenhouse technology, external signals such as irradiance, temperature, daylength, and so on may play a secondary role. In the case of roses, the rhythm is associated with man-induced flowering cycles.

This could also be because $\mathrm{K}$ uptake is an active process (Mengel and Kirkby, 2001) and as Jiménez et al. $(2007,2008)$ observed with phosphorous and $\mathrm{N}$, respectively, mineral elements taken up in an active way are less affected by transpiration stream and consequently VPD. On the other hand, in this case, the period of study was $20 \mathrm{~d}$ and Gent (2008) suggests that plant response to a change in light may be as short as $1 \mathrm{~d}$.

A multiple regression was carried out using $\mathrm{f}(\mathrm{LAI})$ as the principal parameter and including all other variables to improve the model. No other variable would improve the potassium uptake model (Table 4).

Comparison between the different models studied. In a practical way, to estimate nutrient concentration in a nutrient solution, fluctuations in water uptake together with fluctuating nutrient demand must be considered (Zerche, 2000). This work proposes two models to estimate the $\mathrm{K}$ uptake concentration: 1) a fixed concentration value obtained by the slope of the linear correlation between $\mathrm{K}$ uptake and water uptake; and 2) a relation between the estimated $\mathrm{K}$ uptake through the model used LAI and the experimental water uptake. The $1 \%$ error and the SE deviation for all treatments were $0.22,0.43,0.19$, and 0.30 for the fixed value and the model, respectively. The use of a unique $\mathrm{K}$ uptake concentration offers low precision. The second model is closer to the experimental values. 

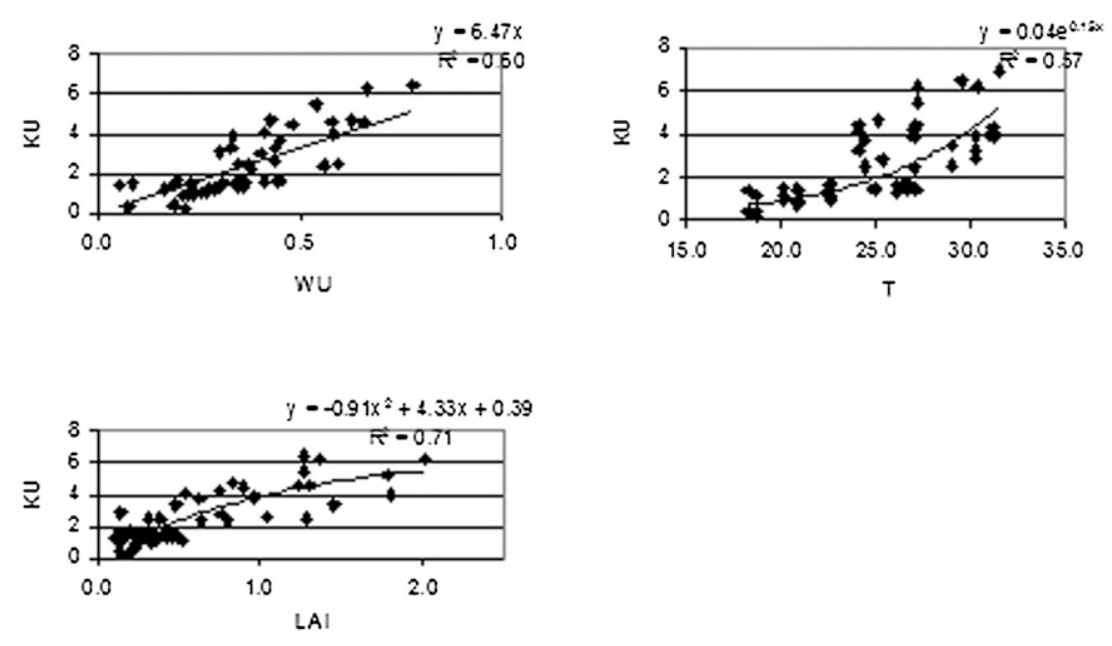

Fig. 3. Simple regression between potassium uptake (mmol/plant/d) and water uptake (WU; L/plant/d), temperature $\left(\mathrm{T} ;{ }^{\circ} \mathrm{C}\right)$, and leaf area index $\left(\mathrm{LAI} ; \mathrm{m}^{2} \cdot \mathrm{m}^{-2}\right)$ for $\mathrm{Ta}, \mathrm{Tb}$, and $\mathrm{Tc}$ treatments. Coefficients are significant at the $0.5 \%$ level.

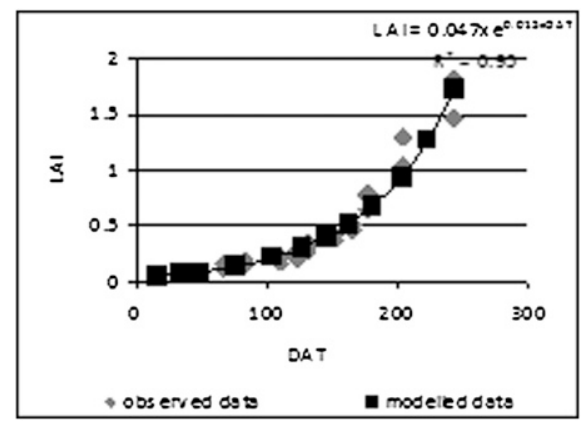

Fig. 4. Leaf area index of modeled and observed data $\left(\mathrm{LAI} ; \mathrm{m}^{2} \cdot \mathrm{m}^{-2}\right)$ during the growth period. $\mathrm{DAT}=$ days after transplanting. Coefficients are significant at the $0.5 \%$ level.

Table 4. Multiple regressions between potassium (K) uptake and climatic and growth parameter for $\mathrm{Ta}, \mathrm{Tb}$, and $\mathrm{Tc}$ treatments in both years.

\begin{tabular}{lcc}
\hline $\begin{array}{l}\text { K uptake } \\
\text { model }\end{array}$ & $R^{2}$ & $\begin{array}{c}\text { Covariance between } \\
\text { independent variables }\end{array}$ \\
\hline $\mathrm{f}[\mathrm{f}(\mathrm{LAI}), \mathrm{T}]^{\mathrm{z}}$ & 0.47 & 0.64 \\
$\mathrm{f}[\mathrm{f}(\mathrm{LAI}), \mathrm{WU}]$ & 0.52 & 0.71 \\
$\mathrm{f}[\mathrm{f}(\mathrm{LAI}), \mathrm{VPD}]$ & 0.46 & 0.26 \\
$\mathrm{f}[\mathrm{f}(\mathrm{LAI}), \mathrm{Rg}]$ & 0.52 & -0.15 \\
\hline${ }^{\mathrm{z}}$ Where $\mathrm{f}(\mathrm{LAI})$ & is $-0.91 *(\mathrm{LAI})^{2}+4.33(\mathrm{LAI})+$
\end{tabular}

${ }^{2}$ Where $\mathrm{f}(\mathrm{LAI})$ is $-0.91 *(\mathrm{LAI})^{2}+4.33(\mathrm{LAI})+$ 0.39 . Coefficients are significant at $0.5 \%$ level.

\section{Conclusion}

Growth period generates important differences in $\mathrm{K}$ concentration changes in the recycled solution. In winter, the $\mathrm{K}$ concentration remains constant, whereas in summer conditions, there is a higher decrease. The source of N applied does not affect K uptake in Dieffenbachia amoena 'Tropic Snow' crop. The study also indicates the possibility of predicting the $\mathrm{K}$ uptake rate and concentration using the proposed models. K uptake can be estimated with a model dependent on the LAI. LAI can be estimated in function of DAT. This model can help the design of a nutritive solution to maintain the recycled solution as much as possible in closed systems and reduce losses in open systems.

\section{Literature Cited}

Adams, P. 2004. Aspectos de nutrición mineral en cultivos sin suelo en relación al suelo, p. 81113. In: Urrestarrazu, M. (ed.). Tratado de cultivo sin suelo. Manuales Universidad de Almería Press, Mundi-prensa, Madrid, Spain.

Alt, D. 1980. Changes in the composition of the nutrient solution during plant growth a factor in soilless culture. Intl. Soc. for Soilless Cult. p. 97-109.

Bar-Tal, A., B. Alón, L. Karni, and R. Rosenberg. 2001. Nitrogen nutrition of greenhouse pepper. II. Effects of nitrogen concentration and $\mathrm{NO}_{3}: \mathrm{NH}_{4}$ ratio on growth, transpiration and nutrient uptake. HortScience 36:1252-1259.

Bloom, A.J. and J. Finazzo. 1986. The influence of ammonium and chloride on potassium and nitrate absorption by barley roots depends on time of exposure and cultivar. Plant Physiol. 81:67-69.

Canavos, G.C. 1988. Probabilidad y Estadística. Madrid, Spain.

Chance, W.O., Z.C. Sonda, and H.A. Mills. 1999. Effect of nitrogen form during the flowering period on zucchini squash growth and nutrient element uptake. J. Plant Nutr. 22:597-607.

D’Agliano, G., C. Carrai, and G. Bigongiari. 1994. Preliminary evaluation of a hydroponic recirculating nutrient system for Gerbera cultivation. Acta Hort. 361:414-422.

Gent, M.P.N. 2008. Density and duration of shade affect water and nutrient use in greenhouse tomato. J. Amer. Soc. Hort. Sci. 133:619-627.

Gislerod, H.R. and A.R. Selmer-Olsen. 1980. The responses of chrysanthemum to variations in salt concentration when grown in recirculated nutrient solution. Acta Hort. 98:201-209.

Guo, S., H. Brück, and B. Sattelmacher. 2002. Effects of supplied nitrogen form on growth and water uptake of Frensch bean (Phaseolus vulgaris L.) plant. Plant Soil 239:267-275. Aplicaciones y Métodos. McGraw Hill,
Jiménez, S., M. Pérez, B.M. Plaza, R. Salinas, and M.T. Lao. 2007. Empirical models of phosphorus uptake under different nitrogen sources in Dieffenbachia amoena 'Tropic Snow'. HortScience 42:1-5.

Jiménez, S., M.L. Segura, and M.T. Lao. 2008 Effect and empirical models of nitrogen uptake under different nitrogen sources in Dieffenbachia amoena. HortScience 43:575-579.

Ju, A.S., R. Shin, and P. Schachtman. 2004. Expression of $K T / K U P$ genes in Arabidopsis and the role of root hairs in $\mathrm{K}^{+}$uptake. Plant Physiol. 134:1135-1145.

Lu, Y.X., C.J. Li, and F.S. Zhang. 2005. Transpiration potassium uptake and flow in tobacco as affected by nitrogen forms and nutrients levels. Ann. Bot. (Lond.) 95:991-998.

Mengel, K. and E.A. Kirkby. 2001. Principles of plant nutrition $5^{\circ}$ Edición. Intl. Potash Inst., Bern, Switzerland.

Mohr, H. and P. Schopfer. 1995. Plant physiology. Springer Verlag, Berlin, Heidelberg, New York

Pardossi, A., F. Falossi, F. Malorgio, L. Incrocci, and G. Bellocchi. 2004. Empirical models of macronutrient uptake in melon plants grown in recirculating nutrient solution culture. J. Plant Nutr. 27:1261-1280.

Rengel, Z. and P. Damon. 2008. Crops and genotypes differ in efficiency of potassium uptake and use. Physiol. Plant. 133:624-636.

Savvas, D., V. Karagianni, A. Kotsiras, V. Demopoulos, I. Karkamisi, and P. Pakou. 2003. Interaction between ammonium and $\mathrm{pH}$ of the nutrient solution supplied to gerbera (Gerbera Jamesonii) grown in pumice. Plant Soil 254:393-402.

Savvas, D., E. Moustaka, N. Mantzos, and P. Barouchas. 2006. Effects of ammonium nitrogen on lettuce grown on pumice in a closed hydroponic system. HortScience 41:1667-1673.

Sheen, T.F. and M.M. Hsu. 1996. Studies on nutrient uptake by greenhouse muskmelon (cucumis melo L.) in hydroponics. Intl. Soc. for Soilless Cult. p. 491-503

Silberbush, M. and J. Ben-Asher. 2001. Simulation study of nutrient uptake by plants from soilless cultures as affected by salinity build up and transpiration. Plant Soil 233:59-69.

Silberbush, M. and J.H. Lieth. 2004. Nitrate and potassium uptake by greenhouse roses (Rosa Hybrida) along successive flower-cut cycles: A model and its calibration. Scientia Hort. 101:127-141.

Sonneveld, C. 2004. La nutrición mineral y salinidad en los cultivos sin suleo: Su manejo, p. 305-368. In: Urrestarrazu M. (ed.). Tratado de cultivo sin suelo. Tratado de cultivo sin suelo Press, Mundi-prensa, Madrid, Spain.

Spanish Ministry of Agriculture and Fishing. 1994 Métodos Oficiales de Análisis. Tomo III. Secretaría General Técnica, Madrid, Spain.

Triboulot, M.B., J. Pritchard, and G. Levy. 1997. Effects of potassium deficiency on cell water relations and elongation of tap and lateral roots of maritime pine seedling. New Phytol. 135:183-190.

Van Goor, B.J., A. de Jager, and W. Voogt. 1988. Nutrient uptake by some horticultural crops during the growing period. Intl. Soc. for Soilless Cult. p. 163-177.

Wang, G., Ch. Li, and F. Zhang. 2003. Effects of different nitrogen forms and combination with foliar spraying with 6-benzylaminopurine on growth, transpiration, and water and potassium uptake and flow in tobacco. Plant Soil 256:169178.

Zerche, S. 2000. Nitrogen demand of cut Chrysanthemums in relation to shoot height and solar radiation. Acta Hort. 511:99-106. 